UNIO - EU Law Journal. Vol. 5, No. 2, July 2019, pp 63-74.

®2019 Centre of Studies in European Union Law

School of Law - University of Minho

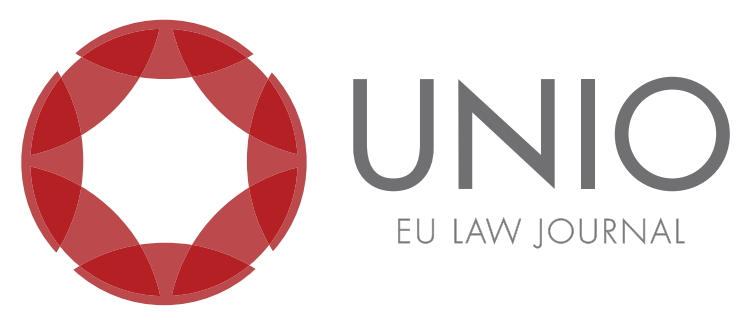

\title{
Digital democracy: from status activus digitalis to disinformation - towards a new wave of judicialization of politics?
}

\author{
Mônia Clarissa Hennig Leal*
}

ABSTR ACT: This Article intends to develop the notion of status activus digitalis as a fundamental legal condition of the individual in times of digital democracy. Participation in procedures and deliberation (status activus processualis) appears as a central element of democracy, a context in which access to information plays a strategic role. In this scenario, the digital environment enhances this participation (status activus digtialis), while the use of fake news affects this information and, consequently, the public debate, representing a real (not fake!) threat to democracy.

KEYWORDS: status activus digitalis - digital democracy - disinformation - judicialization of politics - theory of status (Jellinek and Häberle).

* Coordinator of the Master and PhD Program in Law of the University of Santa Cruz do Sul - UNISC (Brazil). CNPq [National (Brazilian) Council for Scientific and Technological Development] Research Productivity Scholar. 


\section{Introduction ${ }^{1}$}

Based on the theory of status coined by Georg Jellinek and his most relevant updates, this article intends to develop the notion of status activus digitalis as a fundamental legal condition of the individual in times of digital democracy. Although with different foundations and characteristics - which will not be the subject of further analysis here - it is possible to say that the participation of citizens (status activus processualis, as confirmed conformed by Häberle) appears as a central element of theories of democracy, a context in which access to information plays a strategic role. In this scenario, the digital environment enhances this participation (status activus digtialis), but the occurrence of fake news affects this information and, consequently, the public debate, representing a real (not fake!) threat to democracy. Thus, the theory of the status of Jellinek will be approached first. Then, Häberle's notion of status activus processualism - that gives base to the notion of status activus digitalis proposed here will be developed. Finally, the phenomenon of fake news and its repercussions for the exercise of status activus and for democracy will be analyzed.

\section{Status activus digitalis: foundations based on Georg Jellinek's theory of status}

In his work entitled "System der subjektiven öffentlichen Rechten" (published in 1892), GeorgJellinek develops the idea that the individual has different status in his relationship with the State; this status has, in turn, a close relation to fundamental rights, but cannot be identified with them because, in his view, the extension of personality is variable and can be enlarged or diminished in face of the rights assigned to it. ${ }^{2}$

In his relationship with the State, ${ }^{3}$ the individual finds himself in different "status" or positions, being the "status theory", therefore, an attempt to categorize these relations: a) status subjectionis (corresponds to a passive status, in which the individual does not belong to any legal order and therefore is deprived of rights and obligations, being submitted to the State); ${ }^{4}$ b) status negativus (linked to negative rights, allowing the individual a sphere of freedom towards the State - this is, for Jellinek, the fundamental status, corresponding to a prerogative of nonintervention of the State -

\footnotetext{
${ }^{1}$ This article is a result of a research project sponsored by CNPq (Universal Call - Case 403533/2018-0 and Research Productivity Grant - Case 306417/2018 - 9). The research is developed at the "Integrated Center for Studies and Research in Public Policies (CIEPPP)" and at the "Observatory of Latin American Constitutional Jurisdiction" (both funded by FINEP and linked to the Master and PhD Program in Law, UNISC). It also is part of the international cooperation project "Observatory of Latin American Constitutional Jurisdiction”, financed by Capes PGCI 02/2015 - Process 88881.1375114 / 2017-1 and Process 88887.137513 / 2017-00).

${ }^{2}$ Georg Jellinek, Systen der subjektiven öffentlichen Rechte, 2. Auflage [Tübingen: Lizenzausgabe mit freundlicher Genehmigung des Verlags J. C. Mohr (Paul Siebeck), 1919].

${ }^{3}$ Jellinek's theory was developed at the end of the $19^{\text {th }}$ century, taking as a reference a concept based on the notion of Modern State, so that it needs to be updated in a context identified by the transformations and normative plurality to which the States are subjected today [Matthias Jestaed, "Selbstand und Offenheit der Verfassung gegenüber nationalem, supranationalem und internationalem Recht", in Handbuch des Staatsrechts der Bundesrepublik Deutschland. Band XII, Hrsg. v. J. Isensee u. P. Kirchhof (Heidelberg: C.F. Müller, 2014), 327].

${ }^{4}$ According to some authors [Stephan Kirste, "Individualism and collectivism in the foundation of group rights", in Fundamental rights: justification and interpretation, eds. Kenneth Einar Himmah and Bojan Spaic (Amsterdam: Eleven International Publishing, 2018)], this status would have ceased to exist with the "Universal Declaration of Human Rights", which, in its Article 6, states that "Everyone has the right to recognition everywhere as a person before the law."
} 
freedom) $;{ }^{5}$ c) status positivus (associated with positive rights, provided to the citizen by the State; $;^{6}$ ) status activus (linked to active or "participation rights", being identified, from the perspective of the author, with political rights - according to him, it corresponds to the "status of citizenship").

In spite of the current relevance and adequacy of these concepts in the present, some updates of this theory have been proposed over the last years, trying to incorporate to it the complexity and the perceived advances in a scenario characterized by transformations in the conformation of the State and its relations.

Along these lines, one of the most widespread proposals was developed by the German jurist Winfried Brugger, ${ }^{7}$ whose design incorporates the figure of the status europaeus and can be summarized in the following table: ${ }^{8}$

\begin{tabular}{|c|c|c|c|}
\hline $\begin{array}{l}\text { Relationship between } \\
\text { State and individual }\end{array}$ & Problem to be solved & Solution to the problem & $\begin{array}{l}\text { Prominently } \\
\text { analyzed by }\end{array}$ \\
\hline $\begin{array}{l}\text { 1. Sovereignty: individual } \\
\text { subject to the full power } \\
\text { of government - status } \\
\text { subjectionis. }\end{array}$ & $\begin{array}{l}\text { Anarchy, war, rupture of } \\
\text { political or religious power. }\end{array}$ & $\begin{array}{l}\text { National unity, absolute } \\
\text { powers over the people and } \\
\text { over the territory. }\end{array}$ & $\begin{array}{l}\text { Jean Bodin } \\
\text { Thomas Hobbes }\end{array}$ \\
\hline $\begin{array}{l}\text { 2. Freedom: individual with } \\
\text { status libertatis, negativus in } \\
\text { the face of state power. }\end{array}$ & $\begin{array}{l}\text { Aggregation of state } \\
\text { power, usurpation } \\
\text { of powers, resulting } \\
\text { in the exploitation } \\
\text { and super -regulation of } \\
\text { individuals in society. }\end{array}$ & $\begin{array}{l}\text { Separation of powers, } \\
\text { constitutional rights against } \\
\text { powers, federalism, separation } \\
\text { of religion and state. }\end{array}$ & $\begin{array}{l}\text { Montesquieu } \\
\text { John Locke } \\
\text { Immanuel Kant } \\
\text { Federalist Papers }\end{array}$ \\
\hline $\begin{array}{l}\text { 3. Democracy: Individuals } \\
\text { legitimize power through } \\
\text { status activus. }\end{array}$ & $\begin{array}{l}\text { Aggregation of state } \\
\text { power, usurpation of } \\
\text { powers, resulting in political } \\
\text { incapacitation. }\end{array}$ & $\begin{array}{l}\text { Rights of freedom } \\
\text { of expression and of } \\
\text { communication (manifestation } \\
\text { of thought, meeting, } \\
\text { association), right to vote, } \\
\text { right of opposition in } \\
\text { parliament. }\end{array}$ & $\begin{array}{l}\text { Jean- Jaques Rousseau } \\
\text { Immanuel Kant } \\
\text { Federalist Papers }\end{array}$ \\
\hline $\begin{array}{l}\text { 4. Social State: individuals } \\
\text { subsidized by the State in } \\
\text { status positivus. }\end{array}$ & $\begin{array}{l}\text { Government indifference } \\
\text { to the needs of the } \\
\text { population, resulting in the } \\
\text { poverty of the weak and } \\
\text { oppressed. }\end{array}$ & $\begin{array}{l}\text { Social Welfare or the principle } \\
\text { of social justice, incorporation } \\
\text { of social rights to the texts of } \\
\text { the Constitutions. }\end{array}$ & $\begin{array}{l}\text { Lorenz von Stein } \\
\text { Hermann Heller }\end{array}$ \\
\hline $\begin{array}{l}\text { 5. Transnationality I: } \\
\text { individuals organized } \\
\text { among themselves in the } \\
\text { status europaeus. II: individuals } \\
\text { organized among themselves } \\
\text { in the "status universalis". }\end{array}$ & $\begin{array}{l}\text { Existence of very strong/ } \\
\text { weak national States in } \\
\text { Europe, indifference. }\end{array}$ & $\begin{array}{l}\text { Integration of National } \\
\text { States in the European } \\
\text { Union and EU Human Rights } \\
\text { Treaty. }\end{array}$ & $\begin{array}{l}\text { Winston Churchill } \\
\text { Jean Monnet } \\
\text { Robert Schuman } \\
\text { Walter Hallstein }\end{array}$ \\
\hline
\end{tabular}

\footnotetext{
5 "Das Individuum soll vom Staate zu keiner gesetzeswidrigen Leistung herangezogen werden und hat demnach einen auf Anerkennung seiner Freiheit basierten Anspruch auf Unterlassung und Aufhebung der diese Norm überschreitenden obrigkeitlichen Befeble”Jellinek, Systen der subjektiven öffentlichen Rechte.

6 "Der Einzelne erhält die rechtlich geschützte Fähigkeit, positive Leistungen vom Staat zu verlangen und für den Staat die rechtliche Verpflichtung, im Einzelinteresse tätig zu werden” (Jellinek, Systen der subjektiven öffentlichen Rechte). It should be noted, however, that in Jellinek's perspective, those benefits do not correspond to a common interest or to a general welfare concept, since they are conceived as "reflex rights" (Reflexrechte) of the duty of the State; thus, the author recognizes only an individual right to benefits (Jellinek, Systen der subjektiven öffentlichen Rechte).

7 Winfried Brugger, "Georg Jellineks Statuslehre: national und international. Eine Würdigung und Aktualisierung anläßlich seines 100. Todestages im Jahr 2011”, in Integration, Kommunikation und Konfrontation in Recht und Staat. Gesammelte Aufsätze. Hrsg. v. Stephan Kirste u. Helen Brugger (Berlin: Duncker \& Humblot, 2013) advanced in this development, incorporating new status: the status oecologicus and the status culturalis. 8 Winfried Brugger and Mônia Clarissa Hennig Leal, "Os direitos fundamentais nas modernas Constituições: uma abordagem comparativa entre o constitucionalismo alemão e brasileiro a partir da teoria dos status de Jellinek", Revista do Direito, v. 28 (2007).
} 
According to the author, although this summary of the most important stages of modern constitutionalism was formulated for the first time in 1892, its development and updating comprises the entire history of the risks and opportunities represented by the State, not being restricted or applying to a single country or reality only.

1. Status sujbjectionis: recognizing State unlimited sovereign powers produces stabilization in times of anarchy and war.

2. Status negativus: once the problem of anarchy and war is solved, other "basic problems" concerning the notion of sovereignty can take place. Unlimited political power can overlap, exploit, and discriminate parts of the population - hence why it is necessary to advance, in terms of State organization, to the next stage (2). It has to incorporate the principle of freedom, which leads to negative rights, a status in which citizens of a State can self-determine how they want to live their lives and develop their personality. Freedom means having the possibility of choice, implying the right to choose in several of the most important areas of life: choosing a profession, a marriage partner, a political party, a church, religion, etc. And choosing on the basis of freedom also presupposes two more elements: choosing means that there are several other options (not just one partner, group or church, but several); in addition, the right to choose also presupposes that one has the right to choose (the profession, the party, the partner, in which to believe, etc.) without, however, being compelled to do so. In other words, every right to freedom has at the same time an active and a passive aspect. Hence why is it not conceived as possible for a modern State to compel its citizens to choose a particular profession, church, religion or political party. On the other hand, however, it may expect his citizens to work for their own subsistence or to take part in the elections.

3. Status activus: if the right of representation of the interests of all is presented as the central question of constitutionalism, then the guarantee of political freedom presupposes more than not being subjugated by government. This means that government bodies themselves must be established on the basis of the free will of the people. This is the core of the democratic principle as an element of organization of internal power, supplemented by the right to vote of each citizen and freedom of expression of thought, which allows the citizen to form informed opinions about how to regulate public affairs, aspect that leads us to stage three (3) of our picture about the legitimacy of the Constitution?.

4. Status positivus: at this point, legitimate representation of every citizen of a State needs to be fortified. Not every member of society is capable of competing on equal terms and effectively having a good life. There are young and old, as well as sick, for example, too weak to compete. There may also be groups of people traditionally disadvantaged in their life chances by virtue of their ethnic ancestry, the color of their skin or even their religion. If these people have to submit to and accept what the democratic majority decides - without promoting revenge or massacres - then they should be given a chance not only to achieve political representation, but also to have their financial, social and cultural interests considered and protected. That's why

\footnotetext{
${ }^{9}$ It is possible to say that a juridical order characterized by the guarantee of negative fundamental rights and by the corresponding guarantee of separation of Powers, as well as by the protection of the rights of democratic participation, not recognizing social rights, configures what could be designated as a "formal" or "minimal" Constitutional State. This is the model adopted in the United States, while most other modern Constitutions incorporate aspects, especially with regard to social and cultural rights. These Constitutions are often referred to as "material" or as "value" Constitutions [Peter Häberle, Verfassungslebre als Kulturwisseschaft, 2. Auflage (Berlin: Duncker und Humblot, 1998), 368].
} 
stage four (4) integrates most of the Constitutions, either explicitly or implicitly. It implies a fair distribution, or, if necessary, redistribution of social and natural assets, in order to protect the young, the old, the weak, and the disadvantaged sections of the population. It is clear that the principle of social welfare does not replace the general duty that each person should be able to work and take care of herself and family. State protection here is merely subsidiary ${ }^{10}$ in order to guarantee minimum standards of existence for all individuals and groups.

5 Status europaeus: the legitimate representation of the interests of the population finally requires, at this stage (5), an opening of the internal governmental structure to consensus and international law. Empirically, every State (be it old or new, powerful or weak), to some extent, depends on other countries, neighbors or not, for security, economy and culture. But there are also normative issues that point to a need to observe and take into account supranational aspects. If, empirically, a country is dependent on others and becomes stronger having partners, then coordination of matters such as security, economics, and commerce requires the establishment of supranational and international standards of conduct. In the same vein, if a country intends to demonstrate to its population that its actions are legitimate and deserve to be accepted peacefully by all the recipients, then consideration regarding the standards of the other communities becomes necessary. ${ }^{11}$ That is why, after World War II, Europe and the world community engaged in the development of a comprehensive regime of international human rights treaties, as a way to complement and strengthen the constitutional rights of internal order. Europe has even developed institutional supplementation with respect to National States in establishing the European Union. As a result, there are, in Europe, in addition to the internal constitution of each State, two levels of legal integration. ${ }^{12}$

In most Western States, the main function of human and fundamental rights is "negative", which means that these rights are directed against possible abuses of power, against tyranny and against absolute sovereignty, imposing limits on power and governments. The ground that justifies the adoption of such a strategy lies in historical experience itself, which demonstrates that "power corrupts" and that "absolute power corrupts absolutely". This aspect is covered in stages one and two of the schematic picture concerning the evolution of the modern state outlined above. As human and fundamental rights attest, these rights are first seen as "rights of freedom" or "freedom from", especially governmental interference or coercion. In this sense, all organizations and organs of State power, whether horizontal (separation of Powers in Legislative, Executive and Judiciary), or vertical (federalism, different levels of organization and linkage - from the transnational spheres, through the national to the local scope) serve

${ }^{10}$ The notion of positive social rights, proper to social constitutionalism [Mônia Clarissa Hennig Leal, Jurisdição Constitucional aberta: reflexões sobre os limites e a legitimidade da jurisdição constitucional na ordem democrática (Rio de Janeiro: Lumen Juris, 2007), 27] is incorporated here.

${ }^{11}$ Here comparative law and comparative constitutional law in particular gain prominence. This branch of science allows people and its rulers to visualize what solutions have been and are given to certain social and political problems in other countries. That's why Peter Häberle considers comparative constitutional law as "the fifth method of interpretation" [Peter Häberle, "Grundrechtsgeltung und Grundrechtsinterpretation im Verfassungsstaat. Zugleich zur Rechtsvergleichung als "fünfter" Auslegungsmethode“, in Rechtsvergleichung im Kraftfeld des Verfassungsstaates (Berlin: Duncker \& Humblot, 1992)]; according to him, this method naturally does not have a binding force (binding authority), but it can play a persuasive authority.

12 That allows to understand why all books and German Manuals of Constitutional Law contain a chapter on "State Theory" dedicated to work out this integration [Jörn Ipsen, Staatsrecht I, 17. Auflage (München: Luchterhand, 2005)]. 
one and the same purpose: to prevent tyranny and, at the same time, to enable the coordination of State Powers to achieve legitimate purposes. As important as this function is, however, it is not - and could not be - the only one, as the evolution of modern constitutionalism demonstrates. Keeping government away from people, setting limits and legal barriers to their interference in the rights of each individual does not seem enough to legitimize it; it must also become an instrument of the people themselves, which is democratic: a "government of, for and for the people", as the maxim immortalized by Abraham Lincoln preaches. The government must also guarantee rights to weak, poor and/or discriminated individuals or groups. That is why many Constitutions in Eastern European and Latin American countries have developed "positive" functions for human and fundamental rights, in addition to the specific social rights contained in their texts. ${ }^{13}$ These rights, in fact, remain "negative" (that is, they act as a counterpoint and as a limit to State power); but now they also incorporate a "positive" dimension, so that each person or individual can claim to see realized and make use of those same rights. ${ }^{14}$ The purely formal right to defend property or inviolability of the home, for example, is not of great value to those who do not own a property or a house. This is why, as the principle of social welfare demonstrates at a structural level, the defensive function of fundamental rights must be supplemented by a "positive" dimension. ${ }^{15}$

All these aspects, were fundamental in the conformation and consolidation of the Rule of Law, in its different variables. Nowadays, however, in face of the "digital revolution", the possibility (and - why not say - necessity) of developing a new category, identified with a status digitalis, can be seen to explain the condition of individuals and their rights in the context of a highly connected world, in which the space of life is transferred from the real to the virtual.

Before proceeding in this direction however, we will next address the theoretical construction of Peter Häberle on the notion of status activus processualis (parting from the notion of status activus developed by Jellinek), seeking to link it to the challenges of democracy and realization of fundamental rights, and as central element of participation in public affairs.

\section{Status activus digitalis: advancing in Häberle's status activus processualis as central concept of democracy}

Formulating the bases for reflection on fundamental social rights and fundamental rights in the context of the Welfare State (Leistungsstaat), Häberle parts from the

\footnotetext{
${ }^{13}$ As mentioned earlier in this article, this is the point where the American Constitution distances itself from many other modern Constitutions: the former is restricted to securing aspects of democratic organization and power limitation, whereas the latter are characterized by advancing in these aspects and incorporating new contents.

${ }^{14}$ The philosophical foundation of this conception can be found in the work of John Rawls, according to whom the "right to freedom" and the "value of freedom" cannot be dissociated John Rawls, $A$ theory of justice (New York: Ithaca, 1974)].

${ }^{15}$ This process can, in turn, take place in different ways. In Germany, for example, the step to add a positive aspect (financial, organizational, structural and interpretative) to the negative aspect of freedom rights was given by the Constitutional Court, which "invented" these additional functions by developing its case law, in the beginning of the 50's. Since then, Jellinek's "status positivus" can be found in two distinct places in the German Basic Law: in the broad spectrum of rights and in the doctrinal aspects developed to support them [Winfried Brugger, "Konkretisierung des Rechts und Auslegung der Gesetze", in Archiv des öffentlichen Rechts (AöR), Band 119 (Tübingen: J.C.B. Mohr, 1994)].
} 
premise that the - strictly - legal technique, characteristic of the liberal State, is no longer sufficient to account the new demands represented by the positive dimension attributed to those rights, characterized as rights to benefits, directed to the State. ${ }^{16}$

This new reality demands, following the author's words, a new behavior both on the part of the State and the citizens, and its operability cannot be reduced to mere "technicity" (Techniqität); thus, participation and procedure need to take the lead, through cooperative and communicative forms, because constitutional norms have an open character, being endowed with less normative density. Since, however, there is a need for maximum realization of fundamental rights, its implementation - in order to not become arbitrary - needs to recognize a new area of procedural dimension, giving impetus to the notion of status activus processualis developed by Jellinek ${ }^{17}$ once - due to their positive characteristics - they increasingly become the target of organizational and State procedure (weil Grundrechte im Leistungsstaat immer mehr zur Sache staatlicher Organisation und Verfahren werden).

Associated with this perspective - their realization and selection of means is variable ${ }^{18}$ and the object of necessary weighting and decision - there is also the characteristic of the legislative opening inherent in them, a situation in which it is necessary to establish a proportional relationship between the concepts of legislative and procedural elasticity: the more elastic the legislation, the more likely the procedural element (must) enter into play. This is why, within a theory of Social State, the concepts of State and Society must be understood as linked, both of which must be identified with the notion of respublica.

Thus, a (necessary) relationship of cooperation between State and Society has been put in place, a fact that also presupposes the creation of new instruments and mechanisms of participation. ${ }^{19}$ Such a need arises from the perception that the (traditional) status subjectionis does not - and cannot - configure the main status in the context of a democracy, where the relation citizen-State is developed in a communicative and cooperative dimension. ${ }^{20}$

In other words, a transformation takes place in the nature of the realization of fundamental rights; the central element of citizenship is no longer associated with the status passivus subjectionis - characterized by a passive dimension ${ }^{21}$ and protection

\footnotetext{
${ }^{16}$ Rainer Wahl, "Funktionen der Verfassungsgerichtsbarkeit: Schutz vor verfassungswidrigen Recht und Beseitigung von Unsicherheit über den Inhalt des Verfassungsrechts", in Einfübrung in das öffentliche Recht: Verfassung und Verwaltung, Hrsg. Dieter Grimm (Heidelberg: C.F. Müller, 1985), 217.

${ }^{17}$ Jellinek, Systen der subjektiven öffentlichen Rechte.

${ }^{18}$ Robert Alexy, Theorie der Grundrechte (Frankfurt a.M.: Suhrkamp, 1994) faces the question of the possibility of realizing these rights at different levels when speaking of principles as "optimization duties".

${ }^{19}$ This new perspective also introduces the creation of new functional and competence problems, once the traditional form of operationalization reserved for individual negative rights does not appear to be sufficient to accomplish this task; this "crisis of competences" also includes judicial review, demanded in new aspects and in new dimensions.

20 "Obwohl Leistungen auch mit Eingriffen verbunden sein können, ist der ,status passivus subjectionis" nicht mehr der Grundstatus in einer freiheitlichen Demokratie. Das Rechtsverbältnis Bürger-Staat ist gekennzeichnet durch Kommunikation und Kooperation (statt Subjektion!)" Peter Häberle, Grundrechte im Leistungsstaat. Veröffentlichungen der Vereinigung der Deutschen Staatslehrer (VVDStRL), Heft 30. Berichte und Diskussionen auf der Tagung der Vereinigung der Deutschen Staatslehrer in Regensburg vom 29. September bis 2. Oktober 1971 (Berlin: Walter Gruyter, 1972), 59.

${ }^{21}$ This observation includes overcoming the typically modern liberal discourse that identifies citizenship with passive citizenship, that is, being a citizen means being a subject of rights and duties; it is therefore a civil citizenship, extendable to all individuals indistinctly; active citizenship
} 
against interference and State intervention - being transmuted into a markedly active, procedural, and participatory dimension.

These new demands also require a restructuring and an opening of the procedural means, an aspect that leads to the need to strengthen, among other democratic aspects, publicity ${ }^{22}$ in a broad sense, and also an effective incorporation of the interested parties and those affected by decisions dependent on political choices or public policies, resulting and demanding, therefore, an osmosis between State and Society.

Such reality presupposes, however, for its consolidation, equal chances and opportunities of participation, ${ }^{23}$ a situation in which the Democratic State must assume a special responsibility for the realization of fundamental rights. ${ }^{24}$

The status negativus is no longer sufficient to satisfy the demands inherent to this new reality. In such a context, the - revisited - notion of status activus processualis appears as the fundamental status of the democratic State. ${ }^{25}$ This transformation of fundamental rights does not mean a derogation, but only a transformation, in which, alongside with the negative aspect of non-intervention, there is also a demand for participation.

Therefore, fundamental rights have a triple dimension, whose prominence appears as variable: a subjective (defensive), an objective (institutional, where all fundamental rights can be considered social rights in a broad sense), and an active (participation, procedural). ${ }^{26}$

(while a traditional notion inherited from Ancient Greece), identified with the right to participate in public life, appears to be restricted to a small part of the population, not constituting its most important focus [Franz Wieacker, História do Direito Privado Moderno, trans. Antonio Manoel Botelho Hespanha (Lisboa: Fundação Calouste Gulbenkian, 1980)]. The redemption of a more active dimension of citizenship, surpassing this traditional understanding, strongly reappears in the perspective presented here, establishing itself, in Häberle's view, as an essential pillar.

${ }^{22}$ Although there is no formal mention in this sense and Häberle does not develope theoretically the conditions that involve this publicity and this participation, one can perceive here a certain approximation to the communicative theory proposed by Jürgen Habermas, Theorie des kommunikativen Handelns: Handlungs-rationalität und gesellschaftliche Rationalisierung (Frankfurt a.M.: Suhrkamp, 1995).

${ }^{23}$ The aspect of equal opportunities for participation is recurrent in the discussions that involve participation and in the so-called proceduralism. In this sense, it is worth mentioning, as a reference, the notion of "representation reinforcing" sustained by John Hart Ely, Democracy and distrust: a theory of judicial review (Cambridge, Massachusetts: Harvard University Press, 1980) in his classic work "Democracy and distrust", although, there, the accent takes place on the representative aspect, while here the notion of participation is wider and more comprehensive.

${ }^{24}$ The author emphasizes that, at this point, the dogmatics of fundamental rights gains importance; he proposes, thus, the construction of an "open dogmatics", capable of incorporating these mutations and the notion of res publica. Dogmatics and doctrine appear as important instruments of transformation, because they not only reflect change but are also capable of incorporating them into the future - and most of all - on a rational basis. This task of dogmatics is facilitated by the opening of the constitutional text itself, since it allows its development (Fortbildung), although the author criticizes the use of this expression, considering it inadequate, since this action takes place "intra constitutionem".

${ }^{25}$ Some theories try to update the Jellinek's Statuslehre, refounding it and adapting it to the new aspects of reality [Winfried Brugger, Demokratie, Freiheit, Gleichheit: Studien zur Legitimation des Grundgesetzes (Berlin: Duncker \& Humblot, 2002)].

${ }^{26}$ Important to observe that this multiple perspective does not weaken negative rights, such as freedom; on the contrary: it leads to their strengthening, once they are seen as essential element for the exercise of the right to participation, inherent to positive rights and to plurality. 
The status activus is complemented by the negative, positive and passive status, ${ }^{27}$ which implies a re-articulation of the traditionally existing relationship between them. It is a status identified by a highly procedural nature, linked to a right of participation ${ }^{28}$ (Teilhaberecht) - participation in and in the face of the State.

The right to participate in the democratic State is as essential as the position of "citizen" (passive) in the classical Rule of Law, appearing at the procedural aspect as an important element to fortifying the material dimension of fundamental rights. ${ }^{29} \mathrm{It}$ is through the status activus that rights acquire their meaning, which presupposes, first and foremost, an informed citizen, that is engaged and takes his fundamental rights seriously.

Constitution and fundamental rights constitute a res publica, serving as a program and as a substantive reference for the performance of public tasks. ${ }^{30}$

Thus, Häberle takes the concept of status activus (derived from Jellinek's theory) in a broad sense, conceiving participation as an open and pluralistic procedure, ${ }^{31}$ closely related to the idea of publicity and transparency of State activities, which includes not only availability of relevant information, but also the access to "trustful", "clear" and "transparent" data (conceived as an individual and as a collective fundamental right).

In a "digital world", this access to information and participation is (and must be) enhanced, conforming what could be called status activus digitalis, opening up space for new possibilities, but also for new risks to the protection of fundamental rights and to the exercise of democracy.

\section{Status activus digitalis: participation and disinformation in digital democracy}

Internet and social networks have become important field in terms of public debate and narrative dispute, widening space for legitimate and factual discussions, but also opening ways for dissemination of fake news. In addition to this fertile environment for exchange of opinions and public debate, the use of automatic publishing tools allowed the emergence and propagation of BOTs - software controlled accounts that act as humans and actively participate in forums related to political facts of great importance.

Robots are used not only to create identification and increase the group of followers, but also to conduct attacks on opponents and forge artificial discussions. They manipulate debates, create and disseminate false news and influence public

\footnotetext{
${ }^{27}$ As an example, the author cites the the public subsidy offered to private education, where there is an association of freedom of education (negative right) and pluralism sought by the Basic Law with the social aspect represented by access to education. The same occurs in Brazil, where, increasingly, the universalization of the access to higher education is based on private institutions - through grants and financing, for example - more than by free public education. It is, therefore, a right of freedom interpreted socially, which produces a "turnover" (Umschlag) in its classical conception.

${ }^{28}$ In this sense, it should be noted that there are different levels of participation in fundamental rights, and that citizen can appear at different levels at the same time.

${ }^{29}$ Leal, Jurisdição Constitucional aberta.

${ }^{30}$ Here, the constitutionally established right to vote is only a part of it, so that the development of other forms of participation is necessary; moreover, the right of participation to which the "status activus" refers can be both political and social, once it has a broad spectrum.

${ }^{31}$ Häberle, Grundrechte im Leistungsstaat, 1972, 44-131. Die Verfassung wird damit noch nicht zum "juristischen Weltenei”, aus dem alles hervorgeht, sondern wirkligkeitsbezogener Rahmen und Sozialprogramm einer "res publica semper reformanda", Substanz von Aufgaben (Häberle, Grundrechte im Leistungsstaat, 1972, 99).
} 
opinion, posting and replicating messages on a large scale; also promote hashtags that gain prominence with the massification of automated postings, in order to stifle spontaneous debate.

With this kind of manipulation, robots create a false sense of broad political support for a particular proposal, idea or public figure, modifying the direction of public policies, interfering with the stock market, spreading rumors, fake news and conspiracy theories, and generating misinformation and pollution content.

Parties and other social movements also make use of this tool to engage voters, as well as to attack opponents and guide discussions around their interests, using even robot networks (botnets) orchestrated to generate a strong interference in public opinion, by manipulating trending topics ${ }^{32}$ and directing the public debate in general.

This action, which relies on the sharing of links as a means of propagation, tries, at the other hand, to avoid or reduce the weight of the debate on a certain subject. Therefore, robots generate a huge amounts of information that reach users simultaneously to real and relevant information, which end up having their impact diminished or underestimated. So, the use of robots not only disseminates fake news, with harmful effects on society, but also actively seeks to prevent users from informing themselves adequately. ${ }^{33}$

The growth of concerted action of robots represents a real threat to the public debate, presenting risks to democracy, by manipulating the formation of consensuses in the public arena and interfering directly in the selection of representatives - and by means of consequence - in the government agenda responsible for defining the future of the country. ${ }^{34}$

Another phenomenon that contributes to the expansion of fake news is how it is disseminated. Research shows that people tend to interact on social networks with others who share the same thoughts, living in a "bubble" where the circulating information reinforces the same beliefs and opinions (bomophilia).

In a political environment characterized by polarization, rather than admitting the presence of different or conflicting opinions and plurality as something positive, the individual search for elements to reaffirm one's own particular concepts usually tends to incriminate and blame the group at the opposite spectrum for all existing ills. ${ }^{35}$

In this line, the performance of robots is, again, strategic, once bots are based on algorithms, they allow people of each "bubble" to obtain only the information they want to receive. According to Fernández García, "Google crawls between more than 57 variables (for example, computer brand from which it is accessed, location, software used, etc.) to determine the search results that will be most relevant to each person. Facebook also tracks between the clicks of their users what they share and the contacts they interact with, as well as information about the electronic devices they access, information aboutpurchases and transactions within Facebook services

\footnotetext{
${ }^{32}$ According to the author, this kind of actions has been identified in major international politic events, such as the 2010 American elections, Donald Trump's election in 2016 and the UK referendum related to the European Union (Brexit). In Brazil, the dispute for Presidency in 2014 was characterized by a growing political upheaval, coming the robots to motivate about $11 \%$ of the discussions [Marco Aurélio Ruediger, Robôs, redes sociais e política no Brasil: estudo sobre interferências ilegítimas no debate público na web, riscos à democracia e processo eleitoral de 2018 (Rio de Janeiro: FGV, DAPP, 2017), 17].

${ }^{33}$ Ruediger, Robôs, redes sociais e política no Brasil, 10.

${ }^{34}$ Ruediger, Robôs, redes sociais e politica no Brasil, 7.

${ }^{35}$ Renê Morais da Costa Braga, "A indústria das fake news e o discurso de ódio", in Direitos políticos, liberdade de expressão e discurso de ódio, vol. I, org. Rodolfo Viana Pereira (Belo Horizonte: IDDE, 2018), 210, https://goo.gl/xmUwkd.
} 
or information provided by company partners. With all this data, customize the content that shows each user?. ${ }^{36}$

In this context, citizens end up consuming news that are adjusted to their way of thinking, making it difficult to create a pluralistic sphere of dialogue, one of the central aspects of some of the most important theories of democracy nowadays. Democratic information and participation are vitiated, putting at risk precisely the bases on which these conceptions of democracy were developed.

It is important, however, to bear in mind that the use of false news to influence electoral processes always existed. What aggravates this situation in terms of prevalence of digital communication technologies, is the possibility of that content to become viral, by the use of algorithms in social networks. ${ }^{37}$

This process operates what is usually called "post-truth": "It was in 2003. Lying beadlines - oriented, tolerated or induced by the Pentagon - realized that Iraqi dictator Saddam Hussein was manufacturing chemical weapons of mass destruction. Reputable, high-profile newspapers bighlighted this story, which helped convince public opinion that the decision to send US-led troops was well-received with the enthusiastic support of Tony Blair, the British prime minister, invading Iraq. Years later, George W. Bush and Tony Blair admitted that the charge was a frand, but the damage was already done. A survey released in late 2016 showed that 53 percent of Americans still believed that the allegation that Iraq was producing chemical weapons of mass destruction was authentic". ${ }^{38}$

It is clear that the use of this kind of tool that personalizes news and other contents by Facebook and Twitter, in addition to search engines (like Google, for example), accelerates and reinforces the "post-truth" phenomenon. ${ }^{39}$

Moreover, as Oliver ${ }^{40}$ argues, networks are unable to discriminate between real and false news (especially because the criteria of journalism or source-checking do not apply to them); in the same way, neither are users able to make this distinction, thus enhancing, once again, the "post-truth".

\section{Conclusion}

Considering all the elements exposed above, it is possible to conclude, that, paradoxically, at the same time that social networks allow a great mobilization and

\footnotetext{
${ }^{36}$ Nuria Fernández-García, "Fake News: una oportunidad para la alfabetización mediática", Nueva Sociedad, No. 269 (mayo-junio, 2017): 68, www.nuso.org.

${ }^{37}$ Viviane Machado and Hosana Oliveira Duarte, "Fake news nas eleições: ponderações entre a liberdade de informação e o excesso midiático", Interdisciplinary Scientific Journal, No. 4, volume 5, article No. 10 (October/December, 2018): 11, D.O.I: http://dx.doi.org/10.17115/2358-8411/v5n4a10. According to data presented by the author, in the case of the murder of Marielle Franco, in Rio de Janeiro, less than 48 hours after the crime, rumors were published on social networks about her alleged involvement with traffickers. A study by the Public Policy Analysis Board of the Getúlio Vargas Foundation (FGV DAPP) showed that the repercussion of the case motivated 2.1 million posts on Twitter and that the viralization of the factoid parted from one single post (Machado and Oliveira Duarte, "Fake news nas eleições", 10). ${ }^{38}$ Eugenio Bucci, "Pós-política e corrosão da verdade", Revista USP, No. 116 (january/february/ march, 2018): 24.

${ }^{39}$ According to some researches, several of the false reports that influenced the US presidential campaign on the occasion of Donald Trump's election came from sites registered in a small Macedonian city called Veles (Braga, "A indústria das fake news e o discurso de ódio”, 207-208). What's more, even though only $14 \%$ of Americans report that social media was their main source of information in the three months prior to vote, Trump-friendly fake news were shared 30 million times on Facebook, while Clinton's Clinton were shared only 8 million times [S. Enguix Oliver, "Impacto político e informativo de las redes sociales: esferas de actuación y comparación con los médios", Anàlisi. Quaderns de Comunicació i Cultura, 56 (June, 2017): 71-85, DOI: http://dx.doi.org/10.5565/rev/analisi.3090].

${ }^{40}$ Enguix Oliver, "Impacto político e informativo de las redes sociales", 77.
} 
circulation of content, allowing citizens to have a wide access to information - so that he/she can exercise its condition of status activus digitalis (understood as Häberle's status activus processualis in a digital perspective), they put this concept at risk precisely because they could vitiate the public debate, as well as - considering the strategies and manipulations evidenced in the text - compromise the plurality inherent in the democratic environment.

"Digital citizenship" is, therefore, both a blessing and a pest that devastates democracy, and one cannot wait for a swift resolution to this conundrum. It is necessary not only for digital education and normative regulation, but also an effort of citizenship itself, by exercising the status activus digitalis with compromise and pluralistic and critical spirits. 